\title{
Clinical significance of suboptimal hormonal levels in men with prostate cancer treated with LHRH agonists
}

\author{
Jun Kawakami, MD, FRCSC;, Alvaro Morales, MD, FRCSC, OC \\ *Department of Surgery, Division of Urology, University of Calgary, Calgary, AB; 'Department of Urology, Queen's University, Kingston, ON
}

Cite as: Can Urol Assoc J 2013;7:E226-30. htrp://dx.doi.org/10.5489/cuai.540

\section{Abstract}

Purpose: We examined the serum levels of testosterone (T) (total and bioavailable) dehydroepiandrosterone (DHEA), follicle-stimulating hormone $(\mathrm{FSH})$, luteinizing hormone $(\mathrm{LH})$, and prostatespecific antigen (PSA) in men receiving treatment with luteinizing hormone releasing-hormone (LHRH) agonists for metastatic prostate cancer. In doing this, we want to determine the efficacy of these agents in lowering $\mathrm{T}$ levels and whether a possible relationship exists between PSA values, as a surrogate measure of tumour activity, and hormone levels.

Methods: This was a single centre prospective study of patients on LHRH agonists. Of all the 100 eligible patients, 31 did not qualify (10 were receiving their first injection, 13 were on intermittent hormonal therapy, 7 refused to enter the trial and 1 patient's blood sample was lost). Therefore in total, 69 patients were included in the final analysis. Each patient had their blood sample drawn immediately before the administration of a LHRH agonist. The new proposed criteria of $<20 \mathrm{ng} / \mathrm{dL}(0.69 \mathrm{nmol} / \mathrm{L})$ of total testosterone was used to define optimal levels of the hormone in this population. Results: Of the 69 patients, 41 were on goserelin injections, 21 on leuprolide, and 7 on buserelin. There was no statistical difference in hormone levels between any of the medications. Overall, 21\% of patients failed to reach optimal levels of total testosterone. PSA levels were higher in this group. There was a statistically significant correlation between PSA and testosterone levels, as well as between PSA and FSH. Serum levels of PSA, however, did not correlate with those of bioavailable testosterone.

Conclusions: Failure to reach optimal levels of testosterone occurs in patients on LHRH agonist therapy. Higher PSA values are more commonly found in patients with suboptimal levels of testosterone receiving $\mathrm{LHRH}$ analogs, but the clinical importance of this finding has not been established. There is no significant difference with respect to hormonal levels reached among patients on a variety of LHRH agonists. Total testosterone determinations should be considered in patients on LHRH agonist therapy, particularly when the PSA values begin to rise since it may lead to further beneficial hormonal manipulation.

\section{Introduction}

The therapeutic equivalence between bilateral orchidectomy and luteinizing hormone releasing hormone (LHRH) analogs has been accepted for over 2 decades. ${ }^{1}$ Despite the accepted similarity in efficacy, the administration of LHRH analogs is, by and large, the preferred choice for the treatment of carcinoma of the prostate. The concept of similar efficacy between the two methods of androgen suppression has been challenged on the basis that an escape phenomenon occurs in some men treated with gonadotropin agonists and this results in an elevation of serum testosterone above castrate levels, potentially leading to unsatisfactory tumor control..$^{2,3}$

We report on a prospective study aimed at appraising the hypophysis-pituitary-adrenal-gonadal axis by measuring the serum levels of various hormones in patients treated with LHRH agonists for metastatic cancer of the prostate and the significance of the findings in relation to PSA as surrogate gauge of tumour activity.

\section{Methods}

The study was approved by the Institutional Review Board of Queen's University.

\section{Patients}

Over a 12-month period all men with metastatic prostate cancer attending the urology therapy clinic for administration of LHRH analogs were invited to participate in the study. Participants in the study underwent a standard set of blood tests taken immediately before their injection of LHRH agonist. All patients had been on therapy for at least 3 months before entering the study and all complied with the schedule for treatment. 
Biochemistry

Serum aliquots were used for determination of the following hormones: total testosterone $(\mathrm{T})$, bioavailable testosterone (BAT), dihydroepiandrosterone (DHEA), estradiol, folliclestimulating hormone (FSH), luteinizing hormone ( $\mathrm{LH})$ and prolactin. T was determined by an automated immunoassay capable of detection to a level of $0.4 \mathrm{nmol} / \mathrm{L}$. BAT was calculated using the using the values of $\mathrm{T}$, albumin sex hormone binding globulin. ${ }^{4}$ The same serum aliquot was used to determine PSA. The PSA and all other hormone assays were carried out in an automated system. The Elecsys system (Roche Diagnostics) was used for the hormone and PSA tests. We tallied the normal values for the different assays (Table 1). An optimal total testosterone level was defined as less than $20 \mathrm{ng} / \mathrm{dL}(0.69 \mathrm{nmol} / \mathrm{L})$.

In comparing the LHRH agonists, analysis was done including all patients (Table 2) and also excluding patients on maximal androgen blockade (MAB) (Table 3). All other statistical analyses were carried out only on the 47 patients receiving LHRH agonists alone.

\section{Analysis}

The data was not normal in distribution; therefore, non-parametric statistical analyses were performed. The Spearman correlation coefficients were applied to compare the hormone levels to one another. Patients were divided into optimal ( $\mathrm{T}$ levels $\leq 20 \mathrm{ng} / \mathrm{dL}$ ) and non-optimal groups (all others) and analyzed with the Wilcoxon two-sample exact test. Simple mean, medians and standard deviations were also calculated. SAS software was used to analyze the data (SAS Institute, Cary, NC).

\section{Results}

Of the 100 patients available for study, 31 were excluded. Of these 31,10 had insufficient duration of treatment, 13 were on intermittent hormonal therapy, 7 refused to participate,

$\begin{aligned} & \text { Table 1. Tests performed in the study and their normal } \\
& \text { values }\end{aligned}$
\begin{tabular}{lc} 
Test & Normal values \\
\hline Dihydroepiandosterone sulphate & $2.2-15.0 \mathrm{umol} / \mathrm{L}$ \\
Estradiol & $<220 \mathrm{pmol} / \mathrm{L}$ \\
FSH & $<7 \mathrm{U} / \mathrm{L}$ \\
LH & $<9 \mathrm{U} / \mathrm{L}$ \\
Prolactin & $4-18 \mathrm{ug} / \mathrm{L}$ \\
Prostate-specific antigen & $<4 \mathrm{ug} / \mathrm{L}$ \\
Testosterone & $10-28 \mathrm{nmol} / \mathrm{L}$ \\
Bioavailable testosterone & $2.0-8.6 \mathrm{nmol} / \mathrm{L}$ \\
\hline FSH: follicle stimulating hormone; LH: luteinizing hormone. \\
\hline
\end{tabular}

and 1 sample was lost due to a booking error. The range of duration of anti-androgen treatment was 3 to 84 months. The mean duration of treatment was 2.1 years. In total, 69 patients were included in our study. Of these, 22 were on $\mathrm{MAB}$ and 47 patients were on $\mathrm{LHRH}$ agonists alone.

We tallied the T levels of the total 69 patients (Table 2); we further detailed the T levels based on the type of LHRH agonist, excluding MAB (Table 3). T levels $>20 \mathrm{ng} / \mathrm{dL}$ were found in $17 \%(7 / 41), 19 \%(4 / 21)$ and $28 \%(2 / 7)$ of patients on goserelin, leuprolide and buserelin, respectively. There was no statistical difference among the 3 different LHRH agonists used during the study with respect to the proportion of patients not achieving optimal levels of $\mathrm{T}$.

Using the early criteria of $50 \mathrm{ng} / \mathrm{dL}(1.75 \mathrm{nmol} / \mathrm{L})$, we found that only 1 patient would be deemed as having failed to reach a castrate serum level of total testosterone. A different picture emerges when the new criteria for optimal levels $(<20 \mathrm{ng} / \mathrm{dL}$ or $0.69 \mathrm{nmol} / \mathrm{L})$ is applied. In the 47 patients on LHRH agonists alone, $21 \%(10 / 47)$ were found to have suboptimal levels of T. PSA minimum, maximum, median and mean were all higher for the cohort of patients with levels of T $>20 \mathrm{ng} / \mathrm{dL}$ (Table 4).

PSA correlated with total T (correlation 0.42; $p=0.003$ ) and FSH $(0.40 ; p=0.005)$. PSA inversely correlated to prolactin $(-0.33, p=0.03)$ (Table 5).

The values of calculated BAT ranged from 0.01 to 0.16 with a median of 0.05 . The calculated BAT did not correlate with PSA $(0.04, p=0.80)$

\section{Discussion}

At our institution, only 15 surgical castrations have been done over the last 5 years for treatment of metastatic prostate cancer prior to the onset of this study. This disparity in treatment selection is likely due to previous studies proving the efficacy of LHRH agonists, 5,6 the system of drug coverage in the Canadian health system and an unambiguous preference by patients to avoid what they perceive as a "mutilating" and esthetically undesirable procedure.

A decade ago, a strong and valid argument was put forward by Oefelein and colleagues to redefine the "castrate levels" of serum T from $<50 \mathrm{ng} / \mathrm{dL}$ to a new value of $<20 \mathrm{ng} /$ $\mathrm{dL}(0.69 \mathrm{nmol} / \mathrm{L}){ }^{7}$ The question is whether the surgically

\begin{tabular}{|c|c|c|c|c|}
\hline & Gosserelin & Leuprolide & Buserelin & Total (\%) \\
\hline Number & 41 & 21 & 7 & $69(100)$ \\
\hline Castrate T levels & 34 & 17 & 5 & $56(82)$ \\
\hline $\begin{array}{l}\text { Non-castrate } \mathrm{T} \\
\text { levels }\end{array}$ & 7 & 4 & 2 & $13(18)$ \\
\hline
\end{tabular}




\begin{tabular}{|c|c|c|c|c|}
\hline & Gosserelin & Leuprolide & Buserelin & Total (\%) \\
\hline Number & 26 & 15 & 6 & $47(100)$ \\
\hline Castrate $\mathrm{T}$ levels & 22 & 11 & 4 & 37 (79) \\
\hline $\begin{array}{l}\text { Non-castrate T } \\
\text { levels }\end{array}$ & 4 & 4 & 2 & $10(21)$ \\
\hline
\end{tabular}

castrated group has lower T compared to the group on LHRH agonists. Oefelein and colleagues found that only 3 of 35 patients $(8.57 \%)$ who had been surgically castrated had total T levels above $20 \mathrm{ng} / \mathrm{dL} .^{7}$ Our findings on patients treated with LHRH agonists alone show that $21 \%$ of patients $(10 / 47)$ had non-castrate levels of T. Within this more stringent biochemical framework, Oefelein and colleagues have reported non-castrate levels of testosterone in $13 \%$ (5/38) patients on LHRH agonists. ${ }^{2}$ Morote and colleagues found it to be over $12.5 \%{ }^{8}$ and McLeod and colleagues reported $18 \% .{ }^{9}$ It might be inappropriate to compare results across studies, but there appears to be a remarkable consistency among different groups of investigators.

Currently, optimal levels of $\mathrm{T}$ in the treatment of prostate cancer have not been clearly defined, but $<20 \mathrm{ng} / \mathrm{dL}$ $(0.69 \mathrm{nmol} / \mathrm{L})$ are expected for surgical orchidectomy, while $<50 \mathrm{ng} / \mathrm{dL}(1.735 \mathrm{nmol} / \mathrm{L})$ are most common for medical therapy..$^{10}$ If the purpose of androgen ablation is to reach the lowest possible T levels, it appears justified to consider using $\leq 20 \mathrm{ng} / \mathrm{dL}$ as the cut-off for optimal T levels since less than $10 \%$ of patients with bilateral orchiectomies have $\mathrm{T}$ values higher than $20 \mathrm{ng} / \mathrm{dL}(0.69 \mathrm{nmol} / \mathrm{L}){ }^{8}$ In the two papers by Oefelein and colleagues, ${ }^{2,7}$ as well as in our study, such serum levels of testosterone appear to be a significant cut-off as the PSA mean, median, minimum and maximum were all higher for the group with the T greater than $20 \mathrm{ng} / \mathrm{dL}$. Under the old definition of castrate $(50 \mathrm{ng} / \mathrm{dL}$ or $1.735 \mathrm{nmol} / \mathrm{L}$ ), only 1 patient would have had a non-castrate testosterone level and perhaps many patients with $\mathrm{T}$ levels between 20 and $50 \mathrm{ng} / \mathrm{dL}(0.69$ and $1.735 \mathrm{nmol} / \mathrm{L})$ would not have a change in therapy that may help them.

Contrary to these reports, in a recent study, van der Sluis and colleagues ${ }^{11}$ reported lower levels of serum $\mathrm{T}$ in patients treated with $\mathrm{LHRH}$ agonists than those castrated. The study found that all patients had T of $<50 \mathrm{ng} / \mathrm{dL}$ and $97 \%$ had optimal levels. The study was retrospective and a third in the surgically castrated group had the operation as part of gender re-assignment and not for prostate cancer. In this study, the T was measured by isotope-dilution gas chromatography-mass spectrometry (ID/GC-MS/MS), as such the authors, citing a position statement from the Endocrine Society, argue that their results may be more reliable. ${ }^{12}$ The problem with the argument is that the high laboratory standards quoted, as endorsed by the Endocrine Society, refer to the diagnosis of

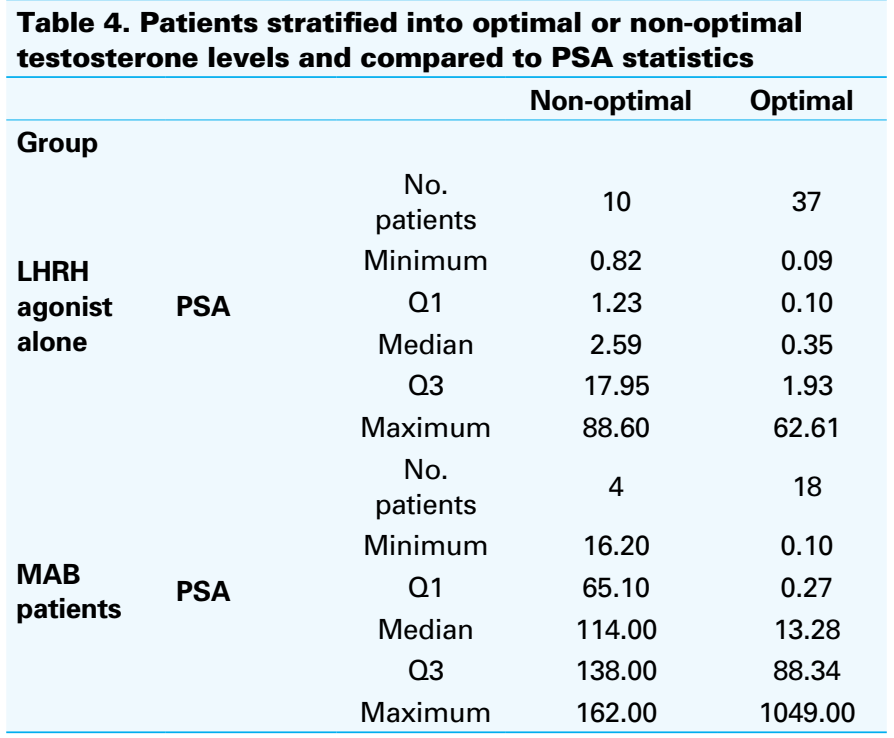

PSA: prostate-specific antigen; LHRH: luteinizing hormone releasing-hormone; Q1: first quartile; Q3: third quartile; MAB: maximal androgen blockade.

hypogonadism and not for monitoring prostate cancer, as indicated in the more recent Endocrine Society guideline. ${ }^{13}$ Currently, the measurement of serum T by ID/GC-MS/MS, although increasingly popular, is more expensive and far from universal.

In terms of the three medications used for medical suppression of androgen production (buserelin, luprolide and goserelin), there was no statistically significant difference in levels of testosterone immediately prior to the next scheduled injection.

PSA is often the proxy early warning sign of clinical relapse of prostate cancer, although a rise in PSA occurs about 6 months before clinical recurrence. ${ }^{14}$ Testosterone should be checked with PSA in patients on LHRH agonists because there is a significant likelihood of higher PSA level with suboptimal levels of serum testosterone. Hintz and colleagues $^{15}$ have rightly noted that a rising PSA does not necessarily indicate a refractory tumour situation; to the contrary, many cases are amenable and responsive to additional hormonal manipulation.

Although others have noted that DHEA administration may accelerate prostate cancer growth, ${ }^{16}$ we did not find a correlation of this steroid with PSA when LHRH analog therapy is used. We found that DHEA-sulfate correlated with calculated BAT, perhaps reflecting that adrenal androgens and peripheral conversion to BAT may cause an elevation of BAT itself. This is, of course, speculation and requires further research. It is surprising, however, to see the lack of correlation between BAT and PSA.

The inverse correlation between PSA and prolactin is interesting but its significance unclear. Dagvadorj and colleagues ${ }^{17}$ reported the intriguing finding that prolactin promotes cell viability of human hormone resistant prostate 


\begin{tabular}{|c|c|c|c|c|c|c|c|c|c|}
\hline & PSA & BAT & DHEAs & Estradiol & FSH & LH & Prolactin & Total T & $\begin{array}{l}\text { Length of } \\
\text { treatment }\end{array}$ \\
\hline $\begin{array}{l}\text { PSA correlation } \\
p \text { value } \\
\text { Number of } \mathrm{px}\end{array}$ & $\begin{array}{c}1.00000 \\
48\end{array}$ & $\begin{array}{c}0.03821 \\
0.7965 \\
48\end{array}$ & $\begin{array}{c}0.20644 \\
0.1592 \\
48\end{array}$ & $\begin{array}{c}0.05801 \\
0.6953 \\
48\end{array}$ & $\begin{array}{c}0.40202 \\
0.0046 \\
48\end{array}$ & $\begin{array}{c}0.14818 \\
0.3148 \\
48\end{array}$ & $\begin{array}{c}-0.32708 \\
0.0248 \\
47\end{array}$ & $\begin{array}{c}0.41892 \\
0.0034 \\
47\end{array}$ & $\begin{array}{c}0.08808 \\
0.5651 \\
45\end{array}$ \\
\hline $\begin{array}{l}\text { BAT correlation } \\
p \text { value } \\
\text { Number of } p x\end{array}$ & $\begin{array}{c}0.03821 \\
0.7965 \\
48\end{array}$ & $\begin{array}{c}1.00000 \\
48\end{array}$ & $\begin{array}{c}0.26249 \\
0.0715 \\
48\end{array}$ & $\begin{array}{c}-0.03321 \\
0.8227 \\
48\end{array}$ & $\begin{array}{c}-0.00862 \\
0.9536 \\
48\end{array}$ & $\begin{array}{c}0.00283 \\
0.9848 \\
48\end{array}$ & $\begin{array}{c}-0.00842 \\
0.9552 \\
47\end{array}$ & $\begin{array}{c}0.14650 \\
0.3258 \\
47\end{array}$ & $\begin{array}{c}0.26630 \\
0.0770 \\
45\end{array}$ \\
\hline $\begin{array}{l}\text { DHEA correlation } \\
p \text { value } \\
\text { Number of } \mathrm{px}\end{array}$ & $\begin{array}{c}0.20644 \\
0.1592 \\
48\end{array}$ & $\begin{array}{c}0.26249 \\
0.0715 \\
48\end{array}$ & $\begin{array}{c}1.00000 \\
48\end{array}$ & $\begin{array}{c}0.05036 \\
0.7339 \\
48\end{array}$ & $\begin{array}{c}0.14353 \\
0.3304 \\
48\end{array}$ & $\begin{array}{c}-0.15363 \\
0.2972 \\
48\end{array}$ & $\begin{array}{c}-0.25469 \\
0.0840 \\
47\end{array}$ & $\begin{array}{c}0.19928 \\
0.1793 \\
47\end{array}$ & $\begin{array}{c}0.17650 \\
0.2461 \\
45\end{array}$ \\
\hline $\begin{array}{l}\text { Estradiol correlation } \\
p \text { value } \\
\text { Number of } \mathrm{px}\end{array}$ & $\begin{array}{c}0.05801 \\
0.6953 \\
48\end{array}$ & $\begin{array}{c}-0.03321 \\
0.8227 \\
48\end{array}$ & $\begin{array}{c}0.05036 \\
0.7339 \\
48\end{array}$ & $\begin{array}{c}1.00000 \\
48\end{array}$ & $\begin{array}{c}0.02445 \\
0.8690 \\
48\end{array}$ & $\begin{array}{c}0.34385 \\
0.0167 \\
48\end{array}$ & $\begin{array}{c}0.15564 \\
0.2962 \\
47\end{array}$ & $\begin{array}{c}0.02302 \\
0.8779 \\
47\end{array}$ & $\begin{array}{c}-0.05656 \\
0.7121 \\
45\end{array}$ \\
\hline $\begin{array}{l}\text { FSH correlation } \\
p \text { value } \\
\text { Number of } p x\end{array}$ & $\begin{array}{c}0.40202 \\
0.0046 \\
48\end{array}$ & $\begin{array}{c}-0.00862 \\
0.9536 \\
48\end{array}$ & $\begin{array}{c}0.14353 \\
0.3304 \\
48\end{array}$ & $\begin{array}{c}0.02445 \\
0.8690 \\
48\end{array}$ & $\begin{array}{c}1.00000 \\
48\end{array}$ & $\begin{array}{c}-0.05425 \\
0.7142 \\
48\end{array}$ & $\begin{array}{c}0.00532 \\
0.9717 \\
47\end{array}$ & $\begin{array}{c}0.13789 \\
0.3553 \\
47\end{array}$ & $\begin{array}{c}-0.02166 \\
0.8877 \\
45\end{array}$ \\
\hline $\begin{array}{l}\text { LH correlation } \\
p \text { value } \\
\text { Number of } \mathrm{px}\end{array}$ & $\begin{array}{c}0.14818 \\
0.3148 \\
48\end{array}$ & $\begin{array}{c}0.00283 \\
0.9848 \\
48\end{array}$ & $\begin{array}{c}-0.15363 \\
0.2972 \\
48\end{array}$ & $\begin{array}{c}0.34385 \\
0.0167 \\
48\end{array}$ & $\begin{array}{c}-0.05425 \\
0.7142 \\
48\end{array}$ & 1.00000 & $\begin{array}{c}0.05787 \\
0.6992 \\
47\end{array}$ & $\begin{array}{c}-0.01443 \\
0.9233 \\
47\end{array}$ & $\begin{array}{c}0.30143 \\
0.0442 \\
45\end{array}$ \\
\hline $\begin{array}{l}\text { Prolactin correlation } \\
p \text { value } \\
\text { Number of } \mathrm{px}\end{array}$ & $\begin{array}{c}-0.32708 \\
0.0248 \\
47\end{array}$ & $\begin{array}{c}-0.00842 \\
0.9552 \\
47\end{array}$ & $\begin{array}{c}-0.25469 \\
0.0840 \\
47\end{array}$ & $\begin{array}{c}0.15564 \\
0.2962 \\
47\end{array}$ & $\begin{array}{c}0.00532 \\
0.9717 \\
47\end{array}$ & $\begin{array}{c}0.05787 \\
0.6992 \\
47\end{array}$ & $\begin{array}{c}1.00000 \\
47\end{array}$ & $\begin{array}{c}-0.19369 \\
0.1971 \\
46\end{array}$ & $\begin{array}{c}-0.08343 \\
0.5903 \\
44\end{array}$ \\
\hline $\begin{array}{l}\text { T correlation } \\
p \text { value } \\
\text { Number of } \mathrm{px}\end{array}$ & $\begin{array}{c}0.41892 \\
0.0034 \\
47\end{array}$ & $\begin{array}{c}0.14650 \\
0.3258 \\
47\end{array}$ & $\begin{array}{c}0.19928 \\
0.1793 \\
47\end{array}$ & $\begin{array}{c}0.02302 \\
0.8779 \\
47\end{array}$ & $\begin{array}{c}0.13789 \\
0.3553 \\
47\end{array}$ & $\begin{array}{c}-0.01443 \\
0.9233 \\
47\end{array}$ & $\begin{array}{c}-0.19369 \\
0.1971 \\
46\end{array}$ & $\begin{array}{c}1.00000 \\
47\end{array}$ & $\begin{array}{c}0.06099 \\
0.6941 \\
44\end{array}$ \\
\hline $\begin{array}{l}\text { Days correlation } \\
p \text { value }\end{array}$ & $\begin{array}{c}0.08808 \\
0.5651\end{array}$ & $\begin{array}{c}0.26630 \\
0.0770\end{array}$ & $\begin{array}{c}0.17650 \\
0.2461\end{array}$ & $\begin{array}{c}-0.05656 \\
0.7121\end{array}$ & $\begin{array}{c}-0.02166 \\
0.8877\end{array}$ & $\begin{array}{c}0.30143 \\
0.0442\end{array}$ & $\begin{array}{l}-0.08343 \\
0.5903\end{array}$ & $\begin{array}{c}0.06099 \\
0.6941\end{array}$ & 1.00000 \\
\hline Number of px & 45 & 45 & 45 & 45 & 45 & 45 & 44 & 44 & 45 \\
\hline
\end{tabular}

cancer and that autocrine prolactin is expressed in over half of those cancer deposits and in over $60 \%$ of metastatic prostate cancer deposits.

In cell culture with immunohistochemical tests, Ben-Josef and colleagues described FSH receptors on prostate cancer cells that are already hormone refractory. ${ }^{18}$ Our clinical finding that FSH was elevated in parallel with higher levels of PSA supports the concept of this molecular mechanism in vivo. This observation suggests that FSH antagonists need to be studied to assess their efficacy in treating the hormoneresistant prostate cancer patient. Similarly, other peptides, such as growth hormone and growth hormone releasinghormone analogs, represent intriguing possibilities for further endocrinological management of these patients.

A consensus meeting and a variety of other studies cited by Gomella ${ }^{10}$ concurred that the benchmark for $\mathrm{T}$ levels should be $\leq 20 \mathrm{ng} / \mathrm{dL}(0.69 \mathrm{nmol} / \mathrm{L})$ for medical castration, similar to surgical orchiectomy. ${ }^{19}$ The most recent guidelines from the European Association of Urology ${ }^{20}$ indicate (without firmly committing) that due to the improvements in the sensitivity of $\mathrm{T}$ assays, this value appears appropriate. The National Comprehensive Cancer Network has agreed that levels $\leq 20 \mathrm{ng} / \mathrm{dL}$ were desirable, ${ }^{21}$ but in the most recent version the Network simply recommend maintaining "castrate serum levels of testosterone."22 These views do not address additional drawbacks associated with all of the LHRH agonists: the initial surge (clinical flare) ${ }^{23}$ and the intermittent mini-surges occurring during treatment after a $T$ nadir has been reached ${ }^{24}$ - both believed to affect survival. ${ }^{25}$ More recently, a large study by Pickles and colleagues ${ }^{26}$ confirmed the occurrence of T breakthroughs during LHRH therapy and documented that once they happen, there is an increased tendency for their recurrence. In this study, a breakthrough was defined as $\geq 1.7 \mathrm{nmol} / \mathrm{L}(50 \mathrm{ng} / \mathrm{dL})$.

Our study, similar to the two studies by Oefelein and colleagues, ${ }^{2,7}$ are cross-sectional and do not provide information on the efficacy of LHRH agonists in achieving the new optimal standard of testosterone nadir. These studies also do not provide information regarding time spans at which the levels of testosterone begin to raise. Only longitudinal evaluations with repeated measurements are capable of elucidating this very important aspect of medical treatment for prostate cancer. It is noteworthy, however, that in the study of Morote and colleagues ${ }^{4}$ there were significant differences in survival-free PSA progression between the group with T levels $>50 \mathrm{ng} / \mathrm{dL}$ and the one with $<20 \mathrm{ng} / \mathrm{dL}$. Whether surgical orchidectomy ${ }^{27}$ or LHRH antagonists ${ }^{28}$ are more beneficial than the agonists remains to be seen. We 
concur with Pickles and colleagues ${ }^{\prime 26}$ recommendation that patients on LHRH agonist should have T evaluations as part of their monitoring.

\section{Conclusions}

Values of total $\mathrm{T} \leq 20 \mathrm{ng} / \mathrm{dL}(0.69 \mathrm{nmol} / \mathrm{L})$, although not yet fully acknowledged, appear to be a clinically useful and significant definition of the optimal range of $\mathrm{T}$ in men undergoing treatment for metastatic prostate cancer. Between 13\% and $21 \%$ of patients fail to achieve or maintain optimal $\mathrm{T}$ levels on LHRH therapy with this standard. The clinical relevance of this difference has not been conclusively established but, suboptimal T levels (>20 ng/dL) correlate with higher PSA values. Currently commercially available LHRH agonists exhibit equivalent efficacy.

Acknowledgments: The authors are indebted to Andrew Day for statistical analysis and Abbott Canada for an unrestricted research grant that allowed the performance of this study.

Competing interests: None declared.

This paper has been peer-reviewed.

\section{References}

1. Vogelzang NJ, Chodak GW, Soloway MS, et al. Goserelin versus orchiectomy in the treatment of advanced prostate cancer: final results of a randomized trial. Urology 1995;46:220-6. http://dx.doi. org/10.1016/50090-4295(99)80197-6

2. Oefelein MG, Cornum R. Failure to achieve castrate levels of testosterone during luteinizing hormone releasing hormone agonist therapy: the case for monitoring serum testosterone and a treatment decision algorithm. J Urol 2000;164:726-9. http://dx.doi.org/10.1016/S0022-5347(05)67290-4

3. Morote J, Orsola A, Planas J, et al. Redefining clinical significant castration levels in patients with prostate cancer receiving continuous androgen deprivation therapy. J Urol 2007;178:1290-5. http://dx.doi. org/10.1016/i.juro.2007.05.129

4. Vermeulen A, Verdonck L, Kaufman JM. A critical evaluation of simple methods for the estimation of free testosterone in serum. J Clin Endocrinol Metab 1999:84:3666-72.

5. Fenandez del Moral P, Dijkman GA, Debruyne FM et al. Three-month depot of goserelin acetate: clinical efficacy and endocrine profile. Urology 1996;48:894-900. http://dx.doi.org/10.1016/S00904295(96)00300-7

6. Sharifi RL, Knoll LD, Smith J, et al. Leuprolide acetate (30-mg depot every four months) in the treatment of advanced prostate cancer. Urology 1998;51:271-6. http://dx.doi.org/10.1016/S00904295(97)00500-1

7. Oefelein MG, Feng A, Scolieri MJ, et al. Reassessment of the definition of castrate levels of testosterone: implications for clinical decision making. Urology 2000;56:1021-4. http://dx.doi.org/10.1016/ S0090-4295(00)00793-7

8. Morote J, Esquena $S$, Abascal JM, et al. Failure to maintain a suppressed level of serum testosterone during long-acting depot luteinizing hormone-releasing hormone agonist therapy in patients with advanced prostate cancer. Urol Int 2006;77:135-8. http://dx.doi.org/10.1159/000093907
9. McLeod D, Zinner N, Gleason D, et al. A phase 3, multicenter, open label randomized study of abarelix versus luprolide acetate in men with prostate cancer. Urology 2001;58:756-61. http://dx.doi. org/10.1016/50090-4295(01)01342-5

10. Gomella LG. Effective testosterone suppression for prostate cancer: Is there a best castration therapy? Rev Urol 2009;12:52-60.

11. van der Sluis TM, Bui HN, Meuleman EJH, et al. Lower testosterone levels with luteinizing hormonereleasing hormone agonist therapy than with surgical castration: new insight attained by mass spectrometry. J Urol 2012;187:1601-7. http://dx.doi.org/10.1016/i.juro.2011.12.063

12. Rosner W, Auchus RJ, Azziz R, et al. Position statement: utility, limitations and piffalls measuring testosterone: en Endocrine Society Position Statement. J Clin Endocrinol Metab 207;92:405-13.

13. Bhasin $S$, Cunningham $G$, Hayes $F$, et al. Testosterone therapy in men with androgen deficiency syndromes: Endocrine Society Clinical Practice Guideline. J Clin Endocrinol Metab 2010;95:2536-59. http://dx.doi. org/10.1210/ic.2009-2354

14. Eisenberger M, Blumenstein $B A$, Crawford $E D$, et al. Bilateral Orchiectomy with or without flutamide in metastatic prostate cancer. New Engl J Med 1998; 33:1036-42. http://dx.doi.org/10.1056/ NEJM199810083391504

15. Hintz BL, Van Nieuwenhuize A, Kagan AR. Prostate-specific antigen-all that rises is not refractory. Urology 2001;57:975-9. http://dx.doi.org/10.1016/S0090-4295(01)00911-6

16. Jones JA, Nguyen $A$, Straub $M$, et al. Use of DHEA in a patient with advanced prostate cancer: a case report and review. Urology 1997;50:784-8. http://dx.doi.org/10.1016/S0090-4295(97)00395-6

17. Dagvadori A, Collins S, Jomain JB, et al. Autocrine prolactin promotes prostate cancer cell growth via janus Kinase-2-signal transducer and activator of transcription-5a/b signaling pathway. Endocrinology 2007;148:3089-101. http://dx.doi.org/10.1210/en.2006-1761

18. Ben-Josef E, Yang $S$, Ji TH, et al. Hormone refractory prostate cancer cells express functional folliclestimulating hormone receptor (FSHR). J Urol 1999;161:970-4. http://dx.doi.org/10.1016/S0022$5347(01) 61831-7$

19. Zlotta A, Debruyne FMJ. Expert opinion on optimal testosterone control in prostate cancer. Eur Urol Suppl 2005;4:37-41. http://dx.doi.org/10.1016/i.eursup.2005.08.005

20. Heidenrich A, Bastian PJ, Bellmunt J, et al. Guideline on Prostate Cancer. European Association of Urology; 2012:80. http://www.uroweb.org/gls/pdf/08\%20Prostate\%20Cancer_LR\%20March\%2013th\%20 2012.pdf. Accessed March 26, 2013

21. National Comprehensive Cancer Network: Prostate cancer. Treatment guidelines for patients. Version 2. 2001.

22. Mohler, JL, Armstrong AJ, Bahnson RR, et al. Prostate Cancer, Version 3.2012. Featured Updates to the NCCN Guidelines. JNCCN 2012;10:1081-7.

23. Zinner NR, Bidair $M$, Centeno $A$, et al. Similar frequency of testosterone surge after repeat injections of goserelin (Zoladex) $3.6 \mathrm{mg}$ and $10.8 \mathrm{mg}$ : results of a randomized open label trial. Urology 2004;64:117781. http://dx.doi.org/10.1016/i.urology.2004.07.033

24. Lepor H, Shore ND. LHRH agonists for the treatment of prostate cancer: 2012. Rev Urol 2012;14:1-2.

25. Perachino M, Cavalli V, Bravi F. Testosterone levels in patients with metastatic prostate cancer receiving continuous androgen deprivation therapy. BJU Int 2010;105:648-51. http://dx.doi.org/10.1111/ i.1464-410X.2009.08814.x

26. Pickles T, Hamm J, Morris WJ, et al. Incomplete testosterone suppression with leuteinizing hormonereleasing hormone agonists: does it happen and does it matter? BJU Int 2012;110(11 Pt B):E500-7. http://dx.doi.org/10.1111/j.1464-410X.2012.11190.x. Epub 2012 May 7.

27. Morales A. Bilateral orchidectomy should not be considered an obsolete alternative for metastatic cancer of the prostate. Can J Urol 2012;19:6414-6.

28. Boccon-Gibod L, van der Meulen E, Persson BE. An update on the use of gonadotropin-releasing hormone antagonists in prostate cancer. Ther Adv Urol 2011;3:127-40. http://dx.doi. org/10.1177/1756287211414457

Correspondence: Dr. Alvaro Morales, 59 Lakeshore Blvd. Kingston, Ontario, K7L 2V7; moralesa@queensu.ca 